\title{
Environmental Impact of High Altitudes on the Operation of PEM Fuel Cell Based UAS
}

\author{
Ibrahim M. Saleh ${ }^{1 *}$, Rashid Ali², Hongwei Zhang ${ }^{1}$ \\ ${ }^{1}$ Materials and Engineering Research Institute, Sheffield Hallam University, Sheffield, UK \\ ${ }^{2}$ Faculty of Engineering, Environment and Computing, Coventry University, Coventry, UK \\ Email: *i.msaleh@hotmail.com, ibrahim.saleh@student.shu.ac.uk, Ac4329@coventry.ac.uk, h.zhang@shu.ac.uk
}

How to cite this paper: Saleh, I.M., Ali, R. and Zhang, H.W. (2018) Environmental Impact of High Altitudes on the Operation of PEM Fuel Cell Based UAS. Energy and Power Engineering, 10, 87-105. https://doi.org/10.4236/epe.2018.103007

Received: January 12, 2018

Accepted: March 27, 2018

Published: March 30, 2018

Copyright (c) 2018 by authors and Scientific Research Publishing Inc. This work is licensed under the Creative Commons Attribution International License (CC BY 4.0).

http://creativecommons.org/licenses/by/4.0/

(c) (i) Open Access

\begin{abstract}
Fuel cell is a device that converts the chemical energy in the reactants into the electrical energy after steps of sequential electrochemical processes with no significant impact on the environment. For high altitude long endurance (HALE) of unmanned aircraft system (UAS) where fuel cell operates as a prime source of power, the operation and performance of a PEM fuel cell at different level of altitudes is vitally important. In this paper, the impact of direct using extracted air from high altitudes atmosphere in order to feed the stack is investigated, and the governing equations of the supplied air and oxygen to the PEM fuel cell stack are developed. The impact of high altitudes upon the operation and the consumption of air are determined in order to maintain certain level of delivered power to the load. Also the implications associated with operating the PEM fuel cell stack at high altitudes and different technical solutions are proposed. Various modes of Integral, Proportional-Integral, and Proportional-Integral-Derivative controller are introduced and examined for different time setting responses in order to determine the most adequate trade-off choice between fast response and reactants consumption which provides the necessary optimization of the air consumption for the developed model of PEM fuel cell used for UAS operation.
\end{abstract}

\section{Keywords}

PEM Fuel Cell, High Altitude, Long Endurance, PID Controller, UAS

\section{Introduction}

Fuel cell is a device that directly converts the energy in the reactants into electricity. Because there is no intermediate thermal conversion process similar to the internal combustion engine or gas turbine, the efficiency of energy conver- 
sion-production for fuel cell is comparatively higher than internal combustion engines. The efficiency of a conventional gasoline combustion engine is around $25 \%-30 \%$, while the efficiency of the fuel cell is two to three times higher than combustion engine depending on the size and type of the fuel cell and its application [1] [2]. The operational temperatures of PEM fuel cell range from $30^{\circ} \mathrm{C}$ to $100^{\circ} \mathrm{C}$ and dynamical response is faster than solid oxide fuel cell which operates at over $700^{\circ} \mathrm{C}[3]$.

In vehicle applications, the time consumed in recharging the battery is longer than the time spent in refuelling the hydrogen storage tank. Therefore major automotive companies such as Ford, Nissan, Daimeler Chrysler are developing electric vehicles based on PEM fuel cells [4]. The response of PEM fuel cell towards the rapid changes in the load demand tends to be slow because the operation of PEM fuel cell depends on monitoring and controlling the flow rate of air-hydrogen, reactants pressure, temperature, management of the produced heat and water as a result of the electrochemical reaction [5].

In a PEM fuel cell, the fuel $\left(\mathrm{H}_{2}\right)$ and oxidant $\left(\mathrm{O}_{2}\right)$ are supplied by mechanical system of pumps and valves. The mechanical adjustment time for these equipments is comparatively longer than the reaction time. This mismatch between the two times causes a real shortage in fuel and oxidant (reactants starvation) which consequently leads to breakdown the chemical reaction and to a rapid drop in the output power of fuel cell. These problems have been addressed by researchers [6] [7] in the control models of fuel cell power systems for hybrid vehicles.

A PEM fuel cell for UAS applications needs a careful water management, particularly for low temperature high altitude environment operations. Also, controlling the fuel cell temperature is a vital issue particularly at high current demand, as it needs a significant volume of air to cool down the stack, which otherwise increases the parasitic losses of the system. However, if the heat transfer from the stack system to the environment and vice versa is managed and controlled effectively by using a proper thermal insulation to maintain the power system within the operational temperature boundaries, thereby reducing the amount of cooling air required, which improves the system efficiency [8].

For high altitude long endurance (HALE) unmanned aircraft systems where a fuel cell operates as a prime source of power, the operation and performance of a PEM fuel cell at different altitudes is vitally important. In particular, for long journeys and high altitudes, wind turbulence and unexpected variations in the load demand make it necessary to find a stable and robust controller which can optimise and provide a fast and sufficient flow of hydrogen and air to the reaction of the fuel cell. This is one of the critical objectives in controlling a PEM fuel cell for UAS applications.

Most of the research literature focus on the complications of supplying air/oxygen to the fuel cell system from the atmospheric ambient at low altitude (up to $300 \mathrm{~m}$ ) UAS applications, or ram air extracted directly from the internal ambient of the fuselage of a conventional commercial airplane. This paper inves- 
tigates the implications associated with operating a PEM fuel cell stack at high altitudes and estimates the required consumption of hydrogen and air/oxygen at various altitudes in order to maintain a certain level of delivered power to the load. Also, it examines the functionality of the PID controller in providing the required gases to the fuel cell system.

\section{Implications of High Altitudes on the Performance of the PEM Fuel Cell}

In the last few years, small numbers of the successful flight tests for the light unmanned aircraft systems powered by fuel cells have been reported. However, most of these tests were restricted to short duration and low altitude flights [9]. At high cruise altitudes of UAS-based fuel cells, where the temperature and pressure are very low, air needs to be compressed in order to raise its pressure to an acceptable operational pressure level, also the fuel and air must be warmed up before being supplied to the stack in order to avoid excessive stack cooling and hence thermal stress caused by cold streams [8].

A water cooling system can be used to maintain stack temperature, but it is not appropriate for UAS applications, as it needs a coolant tank, pump and heat exchanger, which leads to an increase in the size, weight and complexity of the entire system. Therefore, an air cooling system could be considered as an adequate alternative option for cooling the fuel cell stack [10].

Taegyu Kim, et al. [11] proposed that in order to provide a sufficient flow of air to the fuel cell stack system of the UAS, the stack must be located in the front part of the fuselage to directly receive the flow of air through its intake, which is used to feed the cathodes and to cool down the entire system. Sylvie Bégot, et al. [12] reported that it is a complicated task to start-up and to operate the fuel cell stack with sub-zero ambient temperatures, as the water produced in the cathode can turn to ice, which can block the passage of the reactant from reaching the reaction interface. The frozen water can change the conductive properties of the electrodes, membrane, and in the worst cases can damage the membrane. It has been found that the formation of ice would reduce the active surface of the electrode-catalytic layer which reduces the rate of the electrochemical reaction, and hence causing a high drop in the fuel cell output power.

Jürgen Dollmayer, et al. [13] proposed a $700 \mathrm{~kW}$ solid oxide fuel cell system as an alternative source of power to the combined generator and auxiliary power units in the conventional aircraft. Different fuel cell operations are proposed using ram air from the ambient atmosphere with two air temperatures $\left(-24^{\circ} \mathrm{C}\right.$ and $-57^{\circ} \mathrm{C}$ ), and cabin exhaust air at $22^{\circ} \mathrm{C}$. Heat exchangers will work to warm up the stream of air before supply it to the cathode, an auto thermal fuel reformer that uses a warmed air to warm up the stream of hydrogen up to $25^{\circ} \mathrm{C}$ before supply it to the anode, a gas turbine with a generator and condenser for excess water recovery, and an afterburner that works to burn the exhaust air and the hydrogen leaving the cathode and anode of the stack. 
Joseph W. Pratt, et al. [14] investigated the impact of ambient pressure and oxygen concentration on the performance of the PEM fuel cell. In order to simulate the variations in atmospheric conditions from sea level to altitude of $53,500 \mathrm{ft}$. $(16,307 \mathrm{~m})$, the stack of 23 cells was placed inside a vacuum chamber. This provides a pressure variation margin for atmospheric pressure down to 7.2 $\mathrm{kPa}\left(0.072^{\circ} \mathrm{C}\right)$ by using a controlled vacuum pump capable of maintaining a continuous level of desired pressure inside the chamber equivalent to the altitude air pressure; the chamber is thermally insulated from the normal ambient surroundings.

At a high altitude of $11 \mathrm{~km}$, atmospheric temperature and pressure are approximately $-56^{\circ} \mathrm{C}$ and $0.227 \mathrm{bar}$, while air density is around $0.365 \mathrm{~kg} / \mathrm{m}^{3}$, these are severe conditions for a fuel cell to operate. Also, published experimental data for such operating conditions are very limited [14].

Joseph W. Pratt, et al. [14] also reported that Cessna and Boeing have tested a $1.2 \mathrm{~kW}$ Ballard Nexa PEM fuel cell system at pressure of altitudes up to $5000 \mathrm{ft}$. $(1524 \mathrm{~m})$; they showed a drop of $25 \%$ in net power from $1300 \mathrm{~W}$ at sea level to $970 \mathrm{~W}$ at $5000 \mathrm{ft}$. Another test on a Ballard system was carried out by the U.S. Environmental Protection Agency for the altitudes up to $7400 \mathrm{ft}$. $(\sim 2256 \mathrm{~m})$ showed a decline in net power by $24 \%$ compared to the sea level operation. Furthermore, it has been reported that between altitudes of $1000 \mathrm{ft}$. and 10,000 ft., the power output of the fuel cell stack drops by $1.5 \%$ per $1000 \mathrm{ft}$., for a fuel cell using fresh air extracted directly from the atmosphere. However, predicting performance of a fuel cell for altitudes higher than $10,000 \mathrm{ft}$. might be different to the predicted values for lower altitudes, because higher than $10,000 \mathrm{ft}$, the temperature and pressure of the atmosphere drop dramatically to become lower than $-5^{\circ} \mathrm{C}$ and 0.7 bar, which is not an appropriate operational environment for the PEM fuel cell. Therefore, further studies are needed to accurately determine the impact of high altitudes on the performance of the fuel cell stack and its power output, which is very important for the design requirements of fuel cell systems in aerospace applications [14].

\section{PEM Fuel Cell as a Prime Source of Power}

The stack of the PEM fuel cells needs to operate with other components in order to form an integrated fuel cell power system. These components are mainly divided into four systems [15].

- Hydrogen supply system.

- Air supply system.

- Cooling system.

- Humidification system.

Based on the mathematical model of PEM fuel cell which has been developed and proposed by [16], the major electric and thermodynamic variables and parameters involved in the operation of the PEM fuel cell were modelled with the association of the influence of the environment and conditions of the fuel cell 
operation.

Horizon (H-1000) PEM fuel cell stack is used as a prototype device for physically conducting the tests in the Laboratory in order to validate and tune the developed mathematical model with the output results of the tests. The stack is designed to be self-humidified PEM fuel cell stack, four fans are installed at the exit outlet of the manifold of cathode, thus the air system is designed by the manufacture to be ducted outlet, which means the flow of air is controlled by the differential pressure caused by the extractor fans at the exit outlet of the manifold of cathode [16] [17].

In order to maintain flow rate and pressure of hydrogen and air within the desired level, hydrogen and air must be replenished via hydrogen-air supply systems. Hydrogen supply system consists of a tank of pressurised pure hydrogen, inlet flow control valve, outlet purge valve, while air supply system consists of air supply fans, and the connection of the main supply manifold [16]. Figure 1 shows the mechanical components and flow variables of fuel cells stack system at sea level operation.

Horizon Fuel cell stack (H-1000) which has been used in this research is operated with a closed ended anode and using a purge valve instead of open ended anode. A purging anode is important to maintain the internal pressure of hydrogen inside the anode of the fuel cell at appropriate level, also to flush the anodes from the residual unreacted hydrogen and any traces of formed water.

Horizon Fuel Cell Technologies used a purging technique for the fuel cell stack that enables the hydrogen purging process to frequently take place every 10 seconds for a duration of $10 \mathrm{~ms}$. However, this process has a negative impact on the performance of the fuel cell stack, as this leads to a sharp drop in the output voltage, and hence power delivered by the fuel cell. Since the drop in voltage

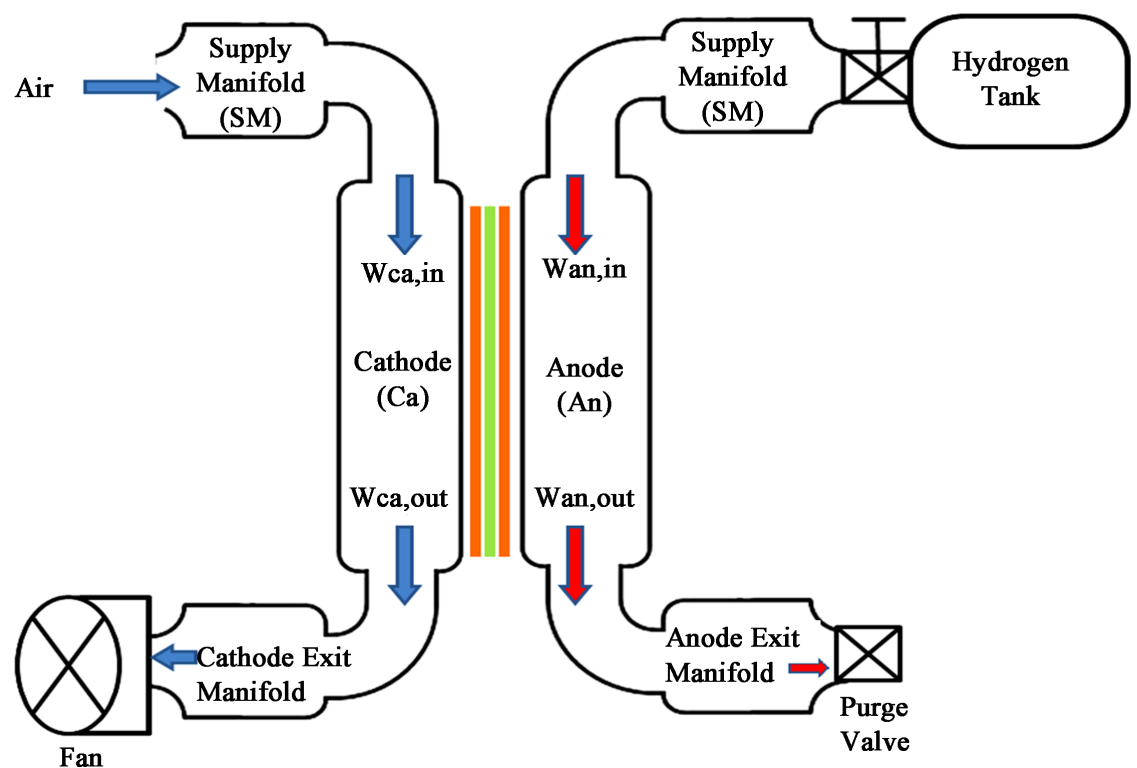

Figure 1. Mechanical components and flow variables of fuel cells stack system at sea level operation. 
lasts for a very short period of time (10 ms), the controller is unable to cope with such a fast transition. A special controller was built by Horizon to switch the fuel cell stack on/off at almost every 10 seconds to overcome the issue of frequent purging of hydrogen, in order to maintain the maximum rated power from the fuel cell stack. However, the proposed controller technique might cause further problems, because of the continuous cycle of turning on/off for the stack, in a cycle of 10 seconds, would lead to unstable the performance and in the worstcase scenario would damage the stack after a period of continuous operation. It also might lead to further delay in the response of the stack toward the change in the load demand [17].

\section{Impact of High Altitudes on the Consumption of Air for a PEM Fuel Cell}

The earth's lower atmosphere, known as the Homosphere, which extends from sea level to $80-100 \mathrm{~km}$, and consists of three layers: Troposphere is lowest layer, the Stratosphere layer extends above the Troposphere, and the Mesosphere layer is above the stratosphere. Within the Homosphere, the main highly concentrated gases are nitrogen $78 \%$, oxygen $21 \%$, and the remaining $1 \%$ is composed of different types of gases such as argon, water vapour, carbon dioxide, methane, ozone, in addition to the traces of inert gases such as neon, helium, and xenon. Within the Homosphere, nitrogen and oxygen are considered as fixed gases where their concentrations are consistent and well mixed at any given altitude [18].

In earth's atmosphere, air density, pressure, and temperature vary with altitude, latitude, longitude, and the season. Air density and pressure decrease exponentially with increasing altitude, the highest air density and pressure are at the sea level [18]. Within Troposphere and up to the height of the Tropopause at $11 \mathrm{~km}(36,089 \mathrm{ft}$.), temperature decreases with the increase in altitude at a constant rate of $-6.5^{\circ} \mathrm{C} / \mathrm{km}\left(-1.98^{\circ} \mathrm{C} / 1000 \mathrm{ft}\right.$.). In the model of international standard atmosphere (ISA), air is considered as a perfect gas within the Troposphere, therefore, temperature and pressure of air at a certain altitude is given by the following equations [18] [19]:

$$
T=T_{o}-((6.5+273.15) * h)
$$

where, $h$ is the altitude in metres, $T_{o}$ is the temperature of the air at sea level in Kelvin which is equal to $288.15 \mathrm{~K}\left(15^{\circ} \mathrm{C}\right)$.

$$
P=P_{o} \cdot\left(1-\left(0.0065 * \frac{h}{288.15}\right)\right)^{5.2561}
$$

where, $P_{o}$ is the pressure of air at sea level which is equal to (101,325 Pa). Using ideal gas law, the density of dry air $\rho\left(\mathrm{kg} / \mathrm{m}^{3}\right)$ at any altitude can be determined as a function of pressure and temperature [20]:

$$
\rho=\frac{P}{R_{s} \cdot T}
$$


where, $R_{s}$ is the specific gas constant for dry air $\left(R_{s}=287 \mathrm{~J} / \mathrm{kg} \cdot \mathrm{K}\right)$, and $T$ is absolute temperature in Kelvin. Relative density of air at certain altitude $(R D)$ is defined as the ratio of the density of air at this altitude $\rho$ to the density of air at sea level $\rho_{o}[18][19]$.

$$
R D=\frac{\rho}{\rho_{o}}=\mathrm{e}^{-\frac{\rho_{o} \cdot h}{R_{s} \cdot T}}
$$

where, $g_{o}$ is the gravitational acceleration of the earth $\left(9.81 \mathrm{~m} / \mathrm{s}^{2}\right)$. For a PEM fuel cell supplied with pure oxygen, the total mass flow rate of the reacted oxygen per second $\left(W_{\mathrm{O}_{2}}\right)$ is determined by $[21]$ :

$$
W_{\mathrm{O}_{2}}=M_{\mathrm{O}_{2}} \cdot \frac{n \cdot I_{s t}}{4 F}
$$

where, $n$ is the number of cells in the stack, $=M_{\mathrm{O}_{2}}$ is the molar mass of oxygen (32 $\mathrm{g} / \mathrm{mol}), I_{s t}$ is the drawn current form fuel cell stack (A), and F is Faraday's constant $(96,485$ Coulombs/mol). In the case where the PEM fuel cell is supplied with fresh air, with molar proportion of oxygen to air is 0.21 [20]. Then, at sea level, the mass flow rate of contributed existing air at the reaction interface of the cathode can be determined as given in Equation (6) below,

$$
W_{\text {air }}=\frac{W_{\mathrm{O}_{2}}}{0.21}=38.1 * \frac{n \cdot I_{s t}}{F}
$$

At any given altitude, the mass flow rate of the contributed existing air at the reaction interface of the cathode can be determined as given in Equation (7) below,

$$
W_{\text {air,altitude }}=\frac{W_{\text {air }}}{R D}
$$

Based on the mathematical model of the PEM fuel cell developed by [16], Horizon (H-1000) PEM fuel cell stack consisting of 72 cells, with a maximum current of $20 \mathrm{~A}$, and by using Equations (5) \& (6) to determine the mass flow rate of contributed existing air at the reaction interface of the cathode at sea level, is found to be equal to $0.569 \mathrm{~g} / \mathrm{s}$.

If at high altitudes the PEM fuel cell is going to be supplied by fresh air extracted from the atmosphere, Equations (1)-(4) can be used to determine the relative density of air at a certain altitude. Then, using Equation (7) it is possible to determine the mass flow rate of the required air at the reaction interface of the cathode to produce a maximum $20 \mathrm{~A}$ current output at various altitudes, as shown in Figure 2.

It is clear that the mass flow rate of necessary consumed air at the reaction interface is increased exponentially with the altitude increase. Theoretically, the ratio of the mass flow rate of consumed air at the reaction interface at an altitude of $10 \mathrm{~km}$ to the consumed air at sea level is equal to $(1.69 / 0.569=2.97)$. Thus, the mass flow rate of the contributed air in the reaction of the PEM fuel cell stack must be increased by $297 \%$ in order to produce the same level of output current at sea level. Yields with more power will be consumed by a compressor 


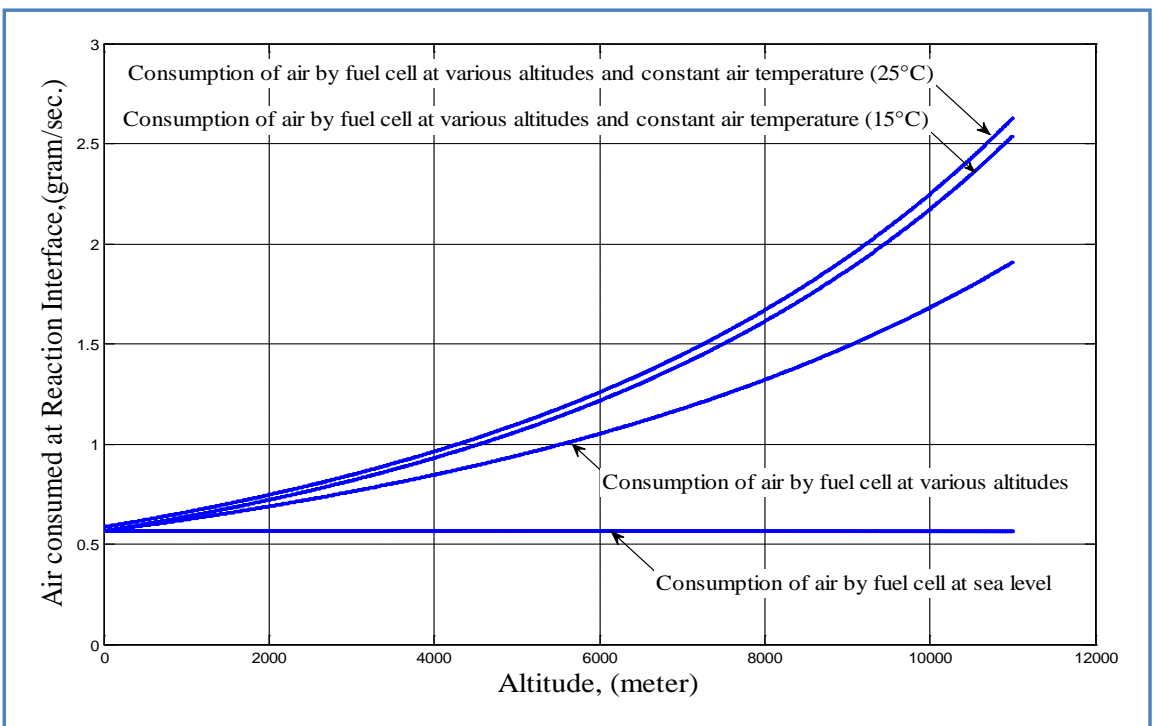

Figure 2. Impact of high altitudes on the mass flow rates of consumed air at the reaction interface for a PEM fuel cell stack being supplied by fresh air.

to raise the flow rate of the supplied air. Such a compressor requires a significant fraction of the generated power, and contributes to increasing the total aircraft weight, which is very difficult to afford in a small scale UAS [9].

In fact, at an altitude of $10 \mathrm{~km}$, the temperature of the air is equal to $-50^{\circ} \mathrm{C}$ and a fuel cell stack does not operate at such low temperature levels, unless special measures are applied to warming up the air before supplying it to the stack. It is assumed that at high altitudes, the PEM fuel cell is going to be supplied by a fresh air from the atmosphere, after warming it up to $15^{\circ} \mathrm{C}$. Similarly, the mass flow rate of required air at the reaction interface of the cathode to produce the maximum current at various altitudes, (at $15^{\circ} \mathrm{C}$ constant temperature of supply air to the stack) can be determined and depicted in Figure 2 above. Therefore, at an altitude of $10 \mathrm{~km}$, and at $15^{\circ} \mathrm{C}$ constant temperature of supply air to the fuel cell stack, the mass flow rate of the necessary consumed air at the reaction interface is $2.18 \mathrm{~g} / \mathrm{s}$, and the ratio of mass flow rate of consumed air at the reaction interface to the consumed air at sea level is equal to $(2.18 / 0.569=3.83)$. Thus, the mass flow rate of contributed air in the reaction of the PEM fuel cell stack must be increased by $383 \%$ in order to produce the same level of output current at sea level.

It is clear that maintaining the temperature of the supplied air to the PEM fuel cell stack at $15^{\circ} \mathrm{C}$ for high altitude operations has an impact of increasing the mass flow rate of the supplied air to the reaction interface, which leads to more power being consumed by the compressor to raise the flow of air. Jürgen Dollmayer, et al. [13] reported for the proposed $700 \mathrm{~kW}$ solid oxide fuel cell system for aircraft applications, that supply streams of air and hydrogen must be warmed up to $25^{\circ} \mathrm{C}$ before supplying it to the fuel cell stack. Also, using cabin exhaust $\left(22^{\circ} \mathrm{C}\right)$ air instead of ram air to supply the fuel cell stack is more efficient in reducing the fuel consumption. 


\section{PID Controller for Air and Hydrogen Supply}

A proportional-integral-derivative (PID) controller is widely used in the industrial and commercial applications [22]. A proportional controller adjusts the speed, the integral part adjusts the steady state error, while the derivative part control regulates the stability and the dynamic response of the system [23].

A PID controller was used to regulate the output voltage at a certain set point via controlling the flow rate of hydrogen and oxygen for a hybrid power-plant system of a 240 W PEM fuel cell stack used for a C-130 Hercules aircraft, as reported by [24].

Hao Chen, et al. [25] used a proportional-integral (PI) controller to control the flow of current between the load, fuel cell/electrolyser stack, solar photovoltaic panel, and the rechargeable batteries for a hybrid energy storage system, in order to extend the endurance of the UAS.

In this research, a PID controller is adopted to control the flow of the fuel and the supplied air to the PEM fuel cell stack, based on determining the current of the fuel cell stack with respect to the changes in the demand current of the connected load. In order to determine the performance of the PID controller due to the changes in the load demand, the following strategy was adopted:

1) The simulation of the PEM fuel cell model will be started from time zero up to the first second, based on the initial value of the current equals to $1 \mathrm{~A}$, with the stack output voltage is equal to $58.2 \mathrm{~V}$.

2) After the first second, the load demand will be increased up to $2 \mathrm{~A}$ and the required power up to $111 \mathrm{~W}$, resulting in an output voltage from the PEM fuel cell stack to be equal to $55.5 \mathrm{~V}$.

3) The simulation will be lasted for four seconds further, in order to achieve five seconds of model simulation.

4) A mechanical adjustment delay of $200 \mathrm{~ms}$ is adopted which corresponds to an arbitrary mechanical delay of flow valve adjustment.

It is observed that the PID controller time response must be tuned between zero and one second, any settings for a time response higher than one second must be avoided as this will cause a delay in the response of the developed model of the PEM fuel cell to the power demand, as shown in Figure 3, for a PID controller with time response setting at 1.35 second, and integral value of 1.4763 .

The responses of the PID controller and time settings are tuned for seven different settings, by adjusting the response time of the controller via using the Auto-Tune function of the PID settings, which automatically determines the values of proportional, integral, and derivative settings, as presented below:

1) Zero delay response: Integral controller with setting response time 0.981 second, at integral value 2.038. The system response reaches outputs of $1.9 \mathrm{~A}$ and $105.8 \mathrm{~W}$ after 0.94 second, and reaches $2 \mathrm{~A}$ and $110.947 \mathrm{~W}$ after 2.62 seconds.

2) Fast response-1: Integral controller with setting response time $0.895 \mathrm{sec}$ ond, at integral value 2.2345. The system response reaches outputs of $1.9 \mathrm{~A}$ and $105.8 \mathrm{~W}$ after 0.7 second, and reaches $2 \mathrm{~A}$ and $110.947 \mathrm{~W}$ after 2.456 seconds. 


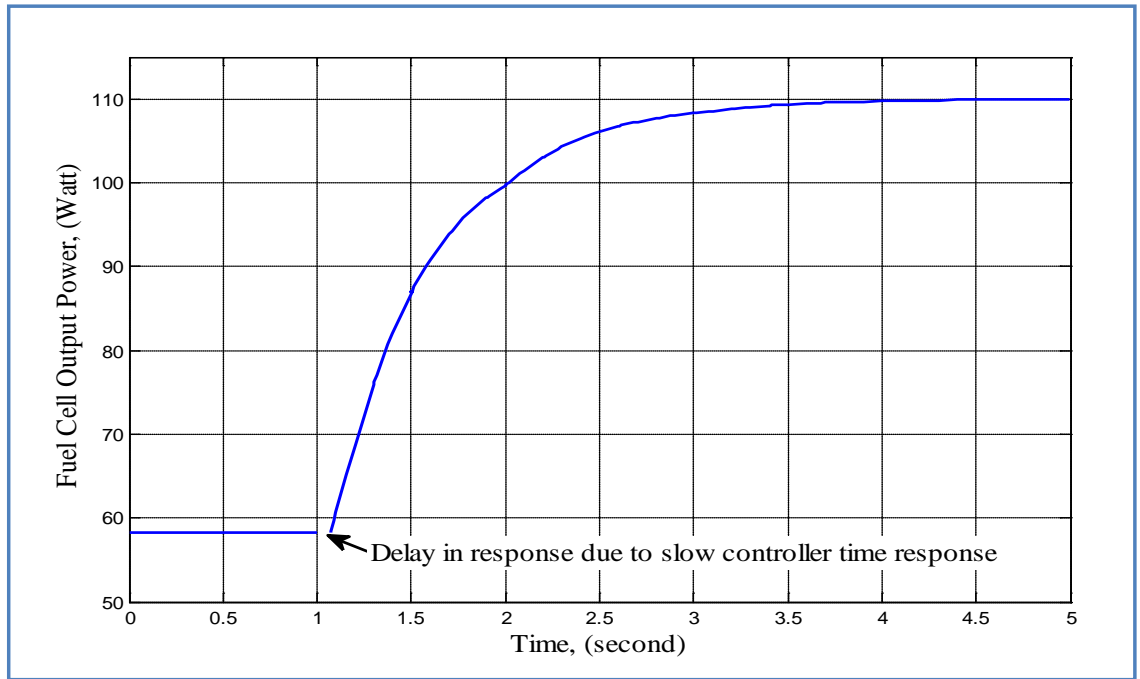

Figure 3. Response of developed PEM fuel cell model to the power demand for PID controller with time response setting at 1.35 second and integral value (1.4763).

3) Fast response-2: Integral controller with setting response time 0.78 second, at integral value 2.5655. The system response reaches outputs of $1.9 \mathrm{~A}$ and 105.8 $\mathrm{W}$ after 0.51 second, and reaches $2 \mathrm{~A}$ and $110.947 \mathrm{~W}$ after 2.373 seconds.

4) Fast response-3: PI controller with setting response time 0.679 second, at proportional value 0.0655 , and integral value 2.9393 . The system response reaches outputs of $1.9 \mathrm{~A}$ and $105.84 \mathrm{~W}$ after 0.41 second, and reaches $2 \mathrm{~A}$ and $110.947 \mathrm{~W}$ after 2.36 seconds.

5) Fast response-4: PI controller with setting response time 0.565 second, at proportional value 0.1837 , and integral value 3.48112 . The system response reaches outputs of $1.9 \mathrm{~A}$ and $105.8 \mathrm{~W}$ after 0.288 second, and reaches $2 \mathrm{~A}$ and $110.943 \mathrm{~W}$ after 2.24 seconds.

6) Overshoot-1: PID controller with setting response time 0.47 second, at proportional value 0.38513 , integral value 3.7623 , and derivative -0.02962 . The system response reaches outputs of $1.9 \mathrm{~A}$ and $105.75 \mathrm{~W}$ at 0.178 second, and reaches $2 \mathrm{~A}$ and $110.5 \mathrm{~W}$ at 2.18 seconds.

7) Overshoot-2, PID controller with setting response time 0.373 second, at proportional value 0.694 , integral value 3.6508 , and derivative -0.065 . The system response reaches outputs of $1.9 \mathrm{~A}$ and $105.8 \mathrm{~W}$ at 0.139 second, then jumps to $2.15 \mathrm{~A}$ and $119 \mathrm{~W}$ at 0.2 second, and settled on $2 \mathrm{~A}$ and $110.9 \mathrm{~W}$ at $2.75 \mathrm{sec}$ onds.

The output responses of the simulation of the developed PEM fuel cell model for various PID settings are presented in Figure 4 and Figure 5, respectively. Table 1 presents the amount of air and hydrogen that needs to be supplied to the developed model of the PEM fuel cell stack in order to deliver the required level of power for the current load varies from $1 \mathrm{~A}$ to $2 \mathrm{~A}$, with different PID controller settings. However, these settings apply only to the developed PEM fuel cell model based on the Horizon (H-1000) stack; other PEM stacks may have different tuning parameters. 


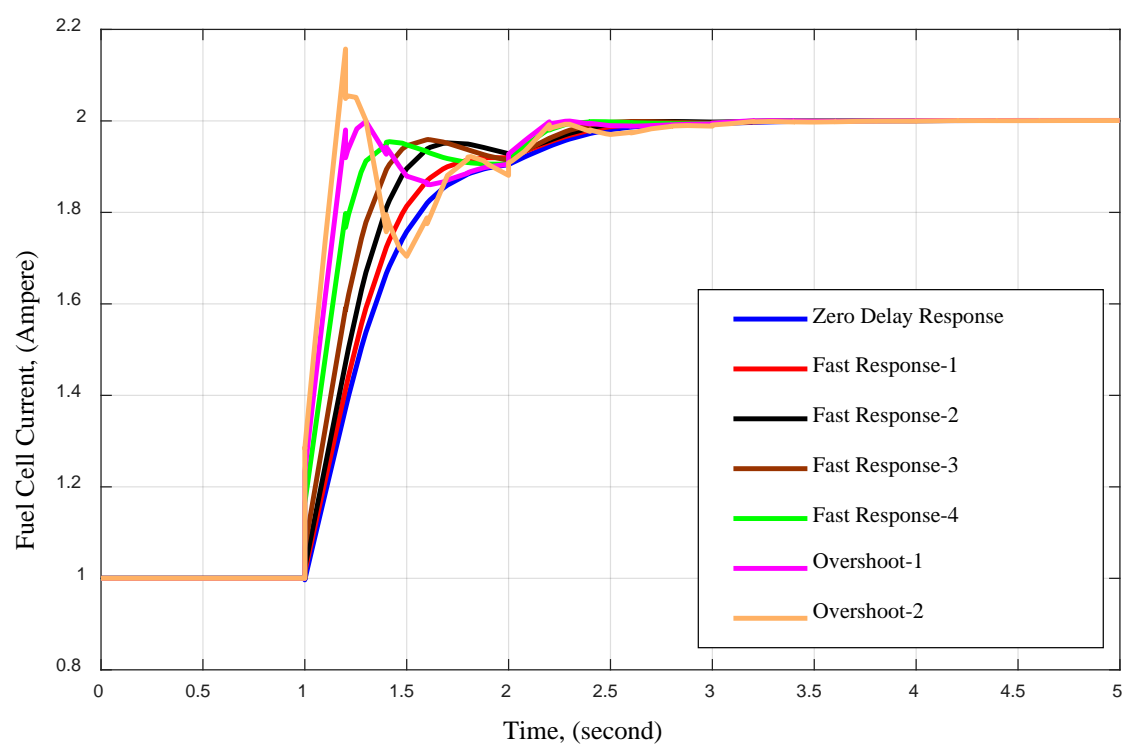

Figure 4. Responses of the developed PEM fuel cell model to the current demand varying from 1 A to $2 \mathrm{~A}$, for PID controller with various response settings.

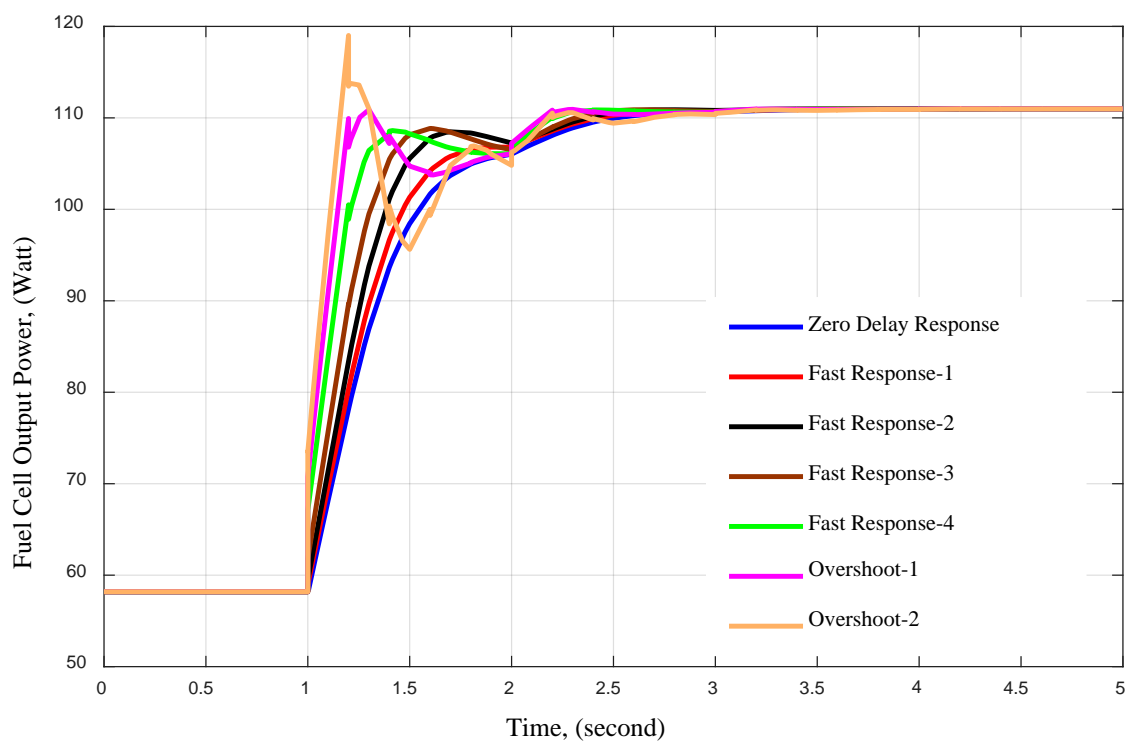

Figure 5. Responses of the developed PEM fuel cell model to the power demand varying from $58.2 \mathrm{~W}$ to $111 \mathrm{~W}$, for PID controller with various response settings.

It is clear that reducing the time response of the PID controller leads to improve the overall response of the system. But, for Overshoot-2, the system starts to take longer time to settle in comparison with Overshoot-1, as shown in Figure 4 and Figure 5. From above results and settings, it can be concluded that the fast response- 3 setting for the PI controller would provide the most adequate trade-off choice between fast response and hydrogen-air consumption, in comparison with the other settings.

Based on the proposed developed model of a PEM fuel cell in [16] and PID controller, the amounts of hydrogen and air required to be supplied to the fuel 
Table 1. Supply air and hydrogen to the developed model of PEM fuel cell stack with current demand varies from $1 \mathrm{~A}$ at $58.2 \mathrm{~W}$ to $2 \mathrm{~A}$ at $111 \mathrm{~W}$, for various PID tuning settings.

\begin{tabular}{ccccc} 
Type of Controller & Response Time (sec.) & Response Type & Supply Air $\mathrm{m}^{3} /$ hour & Supply $\mathrm{H}_{2} \mathrm{~m}^{3} /$ hour \\
\hline Integral & 0.981 & Zero delay & 26.0234 & 0.07677 \\
Integral & 0.895 & Fast response- 1 & 26.1837 & 0.07677 \\
Integral & 0.78 & Fast response-2 & 26.3700 & 0.077882 \\
PI & 0.679 & Fast response-3 & 26.5198 & 0.077882 \\
PI & 0.565 & Fast response-4 & 26.6924 & 0.078995 \\
PID & 0.47 & Overshoot-1 & 26.7577 & 0.078995 \\
PID & 0.373 & Overshoot-2 & 26.6843 & 0.078995
\end{tabular}

cell stack, in order to produce a maximum power output of $877 \mathrm{~W}$ at $20 \mathrm{~A}$ current at different altitudes, where the air is assumed to be extracted from the surrounding ambient under conditions of maintaining hydrogen temperature at $15^{\circ} \mathrm{C}$ and stack temperature at $27.73^{\circ} \mathrm{C}$, are presented in Table 2. While looking at the performance of the fuel cell system model, it became clear that due to drops in the pressure, temperature and density of ambient air at $300 \mathrm{~m}$ altitude, the system stalled. While warming air up to $15^{\circ} \mathrm{C}$ or $20^{\circ} \mathrm{C}$ before supplying it to the fuel cell system lead to reduce the density of the air, which extended the operation of the fuel cell system up to $400 \mathrm{~m}$ altitude, as presented in Table 3 and Table 4, respectively.

It has been reported by [5] [16] [26], that increasing the temperature of the supply fuel and oxidant to a certain level $<30^{\circ} \mathrm{C}$ will lead to warming up the stack of the fuel cell and this will reduce the activation losses via improving the exchange current density of the fuel cell, and hence increasing the output power and improving the performance of the fuel cell stack, which would lead to reduce the rate of fuel and oxidant consumption.

The temperature of the fuel cell will affect the activity of the catalyst, the hydration level of the membrane, the saturation of the gas diffusion layers, and diffusion of gases through the membrane [27]. However, increasing the stack temperature to higher levels should not be the proper solution for improving its output power, because this would dehydrate the membrane and reduce its conductivity, thus increase the ohmic losses of the cell and decline the output power. Figure 6 presents the Simulink block diagram of the proposed PID controller for the developed model of the PEM fuel cell stack system.

\section{High Altitude Operational Hypothesis}

It has been reported in the literature that at high altitudes, where the temperature, pressure and density of air are very low, compressed air and hydrogen can be used to supply the fuel cells with a sustainable source of air or oxygen. Also, fuel and air must be warmed up before being supplied to the stack, in order to 
Table 2. Supply of hydrogen and air to the fuel cell stack based on developed model of PEM fuel cell and PID controller at different altitudes under conditions of fixed hydrogen temperature at $15^{\circ} \mathrm{C}$, constant stack temperature at $27.73^{\circ} \mathrm{C}$, and maximum power output of stack at $877 \mathrm{~W}$ at $20 \mathrm{~A}$ current.

\begin{tabular}{cccccc}
\hline Altitude $(\mathrm{km})$ & $\begin{array}{c}\text { Ambient Air } \\
\text { Pressure }(\mathrm{kPa})\end{array}$ & $\begin{array}{c}\text { Ambient Air } \\
\text { Temp. }\left({ }^{\circ} \mathrm{C}\right)\end{array}$ & $\begin{array}{c}\text { Ambient Air } \\
\text { Density }\left(\mathrm{kg} / \mathrm{m}^{3}\right)\end{array}$ & $\begin{array}{c}\text { Supplied Air } \\
\left(\mathrm{m}^{3} / \text { hour }\right)\end{array}$ & $\begin{array}{c}\text { Supplied } \mathrm{H}_{2} \\
\left(\mathrm{~m}^{3} / \mathrm{hour}\right)\end{array}$ \\
\hline 0 & 101.325 & 15.00 & 1.225 & 97.859 & 0.6364 \\
0.1 & 100.120 & 14.35 & 1.213 & 97.899 & 0.63674 \\
0.2 & 98.945 & 13.70 & 1.202 & 97.942 & 0.63719 \\
0.3 & 97.772 & 13.05 & 1.190 & System Stalled \\
\hline
\end{tabular}

Table 3. Supply of hydrogen and air to the fuel cell stack based on developed model of PEM fuel cell and PID controller at different altitudes under conditions of fixed hydrogen and ambient air temperature at $15^{\circ} \mathrm{C}$, constant stack temperature at $27.73^{\circ} \mathrm{C}$, and maximum power output of stack at $877 \mathrm{~W}$ at $20 \mathrm{~A}$ current.

\begin{tabular}{ccccc}
\hline $\begin{array}{c}\text { Altitude } \\
(\mathrm{km})\end{array}$ & $\begin{array}{c}\text { Ambient Air Pressure Air Density After Warming } \\
(\mathrm{kPa})\end{array}$ & $\begin{array}{c}\text { Supplied Air } \\
\left(\mathrm{m}^{3} / \mathrm{hour}\right)\end{array}$ & $\begin{array}{c}\text { Supplied } \mathrm{H}_{2} \\
\left(\mathrm{~m}^{3} / / \text { hour }\right)\end{array}$ \\
\hline 0 & 101.325 & 1.2250 & 97.859 & 0.6364 \\
0.1 & 100.120 & 1.2107 & 97.897 & 0.63674 \\
0.2 & 98.945 & 1.1965 & 97.934 & 0.6371 \\
0.3 & 97.772 & 1.1823 & 97.971 & 0.6374 \\
0.4 & 96.611 & 1.1682 & \multicolumn{2}{c}{ System Stalled } \\
\hline
\end{tabular}

Table 4. Supply of hydrogen and air to the fuel cell stack based on developed model of PEM fuel cell and PID controller at different altitudes under conditions of fixed hydrogen and ambient air temperature at $20^{\circ} \mathrm{C}$, constant stack temperature at $27.73^{\circ} \mathrm{C}$, and maximum power output of stack at $877 \mathrm{~W}$ at $20 \mathrm{~A}$ current.

\begin{tabular}{ccccc}
\hline $\begin{array}{c}\text { Altitude } \\
(\mathrm{km})\end{array}$ & $\begin{array}{c}\text { Ambient Air Pressure Air Density After Warming } \\
(\mathrm{kPa})\end{array}$ & $\begin{array}{c}\text { Supplied Air } \\
\left(\mathrm{kg} / \mathrm{m}^{3}\right)\end{array}$ & $\begin{array}{c}\text { Supplied } \mathrm{H}_{2} \\
\left(\mathrm{~m}^{3} / \mathrm{hour}\right)\end{array}$ \\
\hline 0 & 101.325 & 1.204 & 97.847 & 0.6363 \\
0.1 & 100.120 & 1.190 & 97.884 & 0.63663 \\
0.2 & 98.945 & 1.176 & 97.920 & 0.63696 \\
0.3 & 97.772 & 1.162 & 97.958 & 0.6373 \\
0.4 & 96.611 & 1.148 & \multicolumn{2}{c}{ System Stalled } \\
\hline
\end{tabular}

avoid excessive stack cooling and hence thermal stress caused by cold streams [8] [14].

In the case of the supply air to the manifold of cathodes is not going to be supplied directly from the external ambient. Instead of that, the air is going to be supplied from a pressurised tank of dry air connected to the supply manifold of cathodes. In order to overcome system stalling issues as presented in Tables 2-4, respectively, due to the drop in atmospheric pressure and temperature, it is necessary to maintain the operational environment of the stack, such as pressure, 


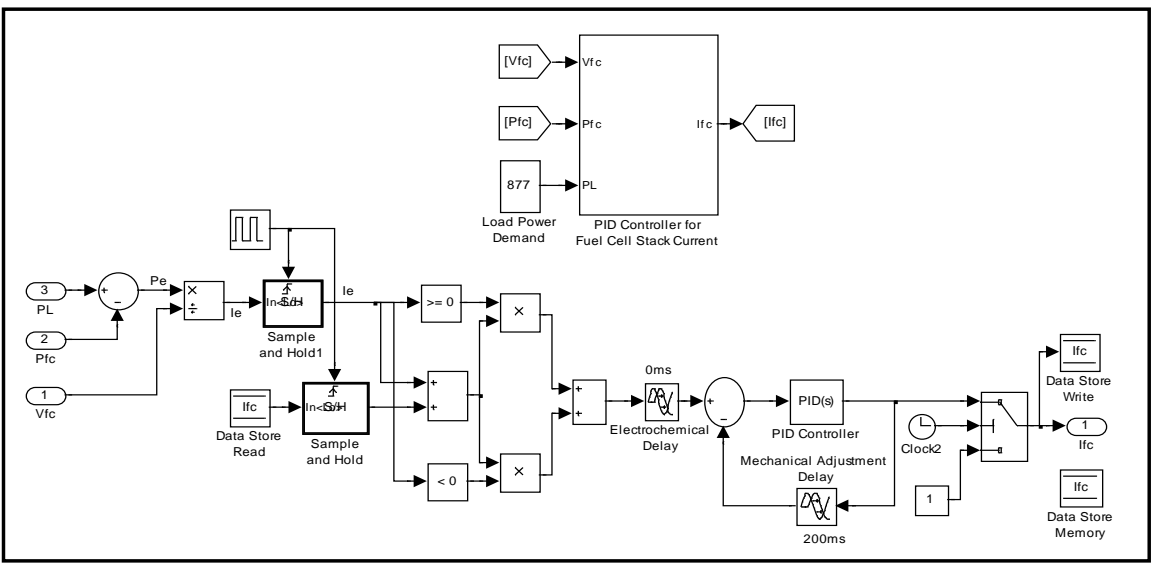

Figure 6. Simulink block diagram of the PID controller for the developed model of the PEM fuel cell stack.

temperature and air humidity as close as possible to conditions at sea level, where the normal operational temperature for the PEM fuel cell stack is between $30^{\circ} \mathrm{C}-90^{\circ} \mathrm{C}$. Therefore, the stack of fuel cells will be considered to be located inside a sealant thermally isolated chamber with an internal ambient pressure and temperature equal to $1 \mathrm{~atm}$ and $15^{\circ} \mathrm{C}$, respectively.

However, a certain amount of unreacted air and hydrogen will leave the stack of the fuel cells associated with water in the form of vapour or liquid, as a result of electrochemical reactions. These residual fluids will accumulate inside the sealant chamber. This will present another operational problem; hence, the air inside the chamber needs to be refreshed in order to maintain a certain operational temperature, relative humidity and pressure approximately close to sea level conditions.

At high altitudes, the pressure inside the chamber containing the fuel cell stack will be higher than altitude pressures. Therefore, any attempt to drain the chamber via opening the drain valve will create a high flow of air at the exit outlet of the chamber as a result of a great pressure difference between the chamber and external atmosphere. This will create a sudden and rapid increment in the flow of air entering the stack which may lead to a spike in the output voltage of the fuel cells; hence, instability in the operation and performance of the stack, and further unnecessary consumption in the usage of air. Also, this may damage the electrolyte membrane due to pressure differences.

The difference between the internal and external pressure of the main stack chamber can be eliminated by either installing a series of sequential settling drain chambers at the exit outlet of the main stack chamber, which can drain the contents (i.e. accumulated gases) of the main stack chamber slowly and sequentially, or by recycling the internal accumulated gases inside the main chamber after a process of refining and gas separating ending with recompressing air and hydrogen again to their storage cylinders, however this option will add more complexity, weight and cost to the entire system.

Figure 7 shows the mechanical components and flow variables associated 


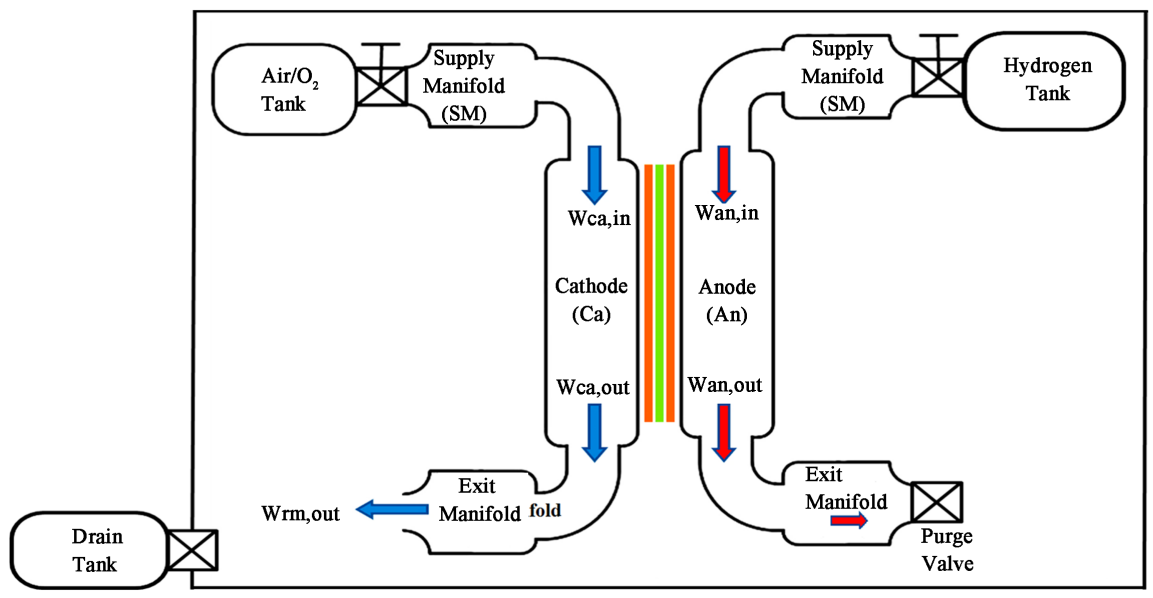

Figure 7. Mechanical components and flow variables associated with proposed model of fuel cells stack system operating at high altitudes.

with the proposed model of a fuel cell stack system operating at high altitudes. The hydrogen and air supply system consists of tanks of pressurised dry air/oxygen and pure hydrogen, inlet pressure regulator valves (PRV), a hydrogen purging valve, drain tank, and connection pipes between the components.

\section{Conclusions}

The impacts of high altitudes on the operation and consumption of the reacted air were determined in order to establish how to maintain a certain level of delivered power to the load. Also, the implications associated with operating a PEM fuel cell stack at high altitudes were considered and different technical solutions were proposed.

It has been proven that warming up the extracted air from the atmosphere at high altitudes $(\sim 10 \mathrm{~km})$ in order to feed the fuel cell stack must be avoided, as this increases the flow of supplied air to the cathode by about $400 \%$ in comparison with the flow at sea level in order to overcome the drop in the density of air at high altitudes and to produce a stable power from the stack, which would add more complexity, weight and cost to the system.

It is clear that due to the drops in the pressure, temperature and density of the ambient air at $300 \mathrm{~m}$ altitude, the fuel cell stack system is stalled. While warming up air up to $15^{\circ} \mathrm{C}$ or $20^{\circ} \mathrm{C}$ before supplying it to the fuel cell system will lead to extend the operation of the fuel cell system up to $400 \mathrm{~m}$ altitude. Moreover, increasing the temperature of the supply fuel and oxidant to a certain level will lead to warming up the stack of the fuel cell and this will reduce the activation losses via improving the exchange current density of the fuel cell, and hence increasing the output power and improving the performance of the fuel cell stack, which would lead to reduce the rate of fuel and oxidant consumption.

Different settings of the PID controller were investigated in terms of optimising the consumption of air and hydrogen and getting a faster time response of the controller, and it was concluded that a proportional-integral (PI) controller 
with time response of 0.679 second at a proportional value of 0.0655 , and integral value of 2.9393, will offer the most adequate trade-off choice between fast response and hydrogen-air consumption, in comparison with other settings, which can be used for optimising the consumptions of air and hydrogen for the developed model of PEM fuel cell used for high altitude UAS operation.

\section{References}

[1] Golbert, J. and Lewin, D.R. (2004) Model-Based Control of Fuel Cells: (1) Regulatory Control. Journal of Power Sources, 135, 135-151. https://doi.org/10.1016/j.jpowsour.2004.04.008

[2] El-Sharkh, M.Y., Rahman, A., Alam, M.S., Byrne, P.C., Sakla, A.A. and Thomas, T. (2004) A Dynamic Model for a Stand-Alone PEM Fuel Cell Power Plant for Residential Applications. Journal of Power Sources, 138, 199-204. https://doi.org/10.1016/j.jpowsour.2004.06.037

[3] Bordons, C., Arce, A. and Real, A.J.D. (2006) Constrained Predictive Control Strategies for PEM Fuel Cells. American Control Conference, Minneapolis, Minnesota, USA.

[4] Pukrushpan, J.T., Stefanopoulou, A.G. and Peng, H. (2004) Control of Fuel Cell Breathing. IEEE Control Systems Magazine, 24, 30-46.

https://doi.org/10.1109/MCS.2004.1275430

[5] Abul-Hawa, A.A., Ebaid, M.S., Bhinder, F.S. and Calay, R.K. (2006) Control strategy for polymer electrolyte membrane fuel cell systems. in Procs UKACC Int Conf Control Paper 94. 2006: University of Strathclyde Publishing.

[6] Rodatz, P., Paganelli, G., Sciarretta, A. and Guzzella, L. (2005) Optimal Power Management of an Experimental Fuel Cell/Supercapacitor-Powered Hybrid Vehicle. Journal of Control Engineering Practice, 13, 41-53. https://doi.org/10.1016/j.conengprac.2003.12.016

[7] Phatiphat Thounthong, S.e. Ra“el, and B. Davat, (2006) Control Strategy of Fuel Cell/Supercapacitors Hybrid Power Sources for Electric Vehicle. Journal of Power Sources, 158, 806-814. https://doi.org/10.1016/j.jpowsour.2005.09.014

[8] Aguiar, P., Brett, D.J.L. and Brandon, N.P. (2008) Solid Oxide Fuel Cell/Gas Turbine Hybrid System Analysis for High-Altitude Long-Endurance Unmanned Aerial Vehicles. International Journal of Hydrogen Energy, 33, 7214-7223. https://doi.org/10.1016/j.ijhydene.2008.09.012

[9] Renau, J., Lozano, A., Barroso, J., Miralles, J., Martín, J., Sánchez, F. and Barreras, F. (2015) Use of Fuel Cell Stacks to Achieve High Altitudes in Light Unmanned Aerial Vehicles. International Journal of Hydrogen Energy, 40, 14573-14583. https://doi.org/10.1016/j.ijhydene.2015.02.071

[10] Kim, K., Kim, T., Lee, K. and Kwon, S. (2011) Fuel Cell System with Sodium Borohydride as Hydrogen Source for Unmanned Aerial Vehicles. Journal of Power Sources, 196, 9069-9075. https://doi.org/10.1016/j.jpowsour.2011.01.038

[11] Kim, T. and Kwon, S. (2012) Design and Development of a Fuel Cell-Powered Small Unmanned Aircraft. International Journal of Hydrogen Energy, 37, 615-622. https://doi.org/10.1016/j.ijhydene.2011.09.051

[12] Bégot, S., Harel, F., Candusso, D., François, X., Péra, M.-C. and Yde-Andersen, S. (2010) Fuel Cell Climatic Tests Designed for New Configured Aircraft Application. Energy Conversion and Management, 51, 1522-1535. https://doi.org/10.1016/j.enconman.2010.02.011 
[13] Dollmayer, J., Bundschuh, N. and Carl, U.B. (2006) Fuel Mass Penalty Due to Generators and Fuel Cells as Energy Source of the All-Electric Aircraft. Aerospace Science and Technology, 10, 686-694. https://doi.org/10.1016/j.ast.2006.08.001

[14] Pratt, J.W., Brouwer, J. and Samuelsen, G.S. (2007) Performance of Proton Exchange Membrane Fuel Cell at High-Altitude Conditions. Journal of Propulsion and Power, 23, 437-444. https://doi.org/10.2514/1.20535

[15] Pukrushpan, J.T., Peng, H. and Stefanopoulou, A.G. (2002) Simulation and Analysis of Transient Fuel cell System Performance Based on a Dynamic Reactant Flow Model. Proceedings of International Mechanical Engineering Congress \& Exposition (IMECE 2002), New Orleans, LA, 17-22 November 2002, 637-648.

[16] Saleh, I.M.M., Ali, R. and Zhang, H. (2016) Simplified Mathematical Model of Proton Exchange Membrane Fuel Cell Based on Horizon Fuel Cell Stack. Journal of Modern Power Systems and Clean Energy, 4, 668-679. https://doi.org/10.1007/s40565-016-0196-5

[17] Horizon Fuel Cell Technology, H-1000 Fuel Cell Stack-User Manual, Horizon Fuel Cell Technology, 18 May 2011.

[18] Jacobson, M.Z. (2005) Fundamentals of Atmosphere Modeling. 2nd Edition, Cambridge University Press, Cambridge.

[19] Cavcar, M. (2000) The International Standard Atmosphere (ISA). http://home.anadolu.edu.tr/ mcavcar/common/ISAweb.pdf

[20] Turns, S.R. (2006) Thermodynamics: Concepts and Applications. Cambridge University Press, Cambridge.

[21] Larminie, J. and Dicks, A. (2003) Fuel Cell Systems Explained. 2nd Edition, John Wiley \& Sons Ltd., Hoboken.

[22] Tan, K.K., Huang, S. and Ferdous, R. (2002) Robust Self-Tuning PID Controller for Nonlinear Systems. Journal of Process Control, 12, 753-761. https://doi.org/10.1016/S0959-1524(02)00005-7

[23] Burns, R.S. (2001) Advanced Control Engineering. Butterworth-Heinemann, Oxford.

[24] Radmanesh, H., Yazdi, S.S.H., Fathi, S.H. and Gharehpetian, G.B. (2014) Modelling and Simulation of Fuel Cell Dynamics for Electrical Energy Usage of Hercules Airplanes. The Scientific World Journal, 2014, Article ID: 593121.

[25] Chen, H. and Khaligh, A. (2010) Hybrid Energy Storage System for Unmanned Aerial Vehicle (UAV). IECON2010-36th Annual Conference on IEEE Industrial Electronics Society, IEEE, 2851-2856.

[26] Amphlett, J.C., Mann, R.F., Peppley, B.A., Roberge, P.R. and Rodrigues, A. (1996) A Model Predicting Transient Responses of Proton Exchange Membrane Fuel Cells. Journal of Power Sources, 61, 183-188. https://doi.org/10.1016/S0378-7753(96)02360-9

[27] Verstraete, D., Lehmkuehler, K., Gong, A., Harvey, J.R., Brian, G. and Palmer, J.L. (2014) Characterisation of a Hybrid, Fuel-Cell-Based Propulsion System for Small Unmanned Aircraft. Journal of Power Sources, 250, 204-211. https://doi.org/10.1016/j.jpowsour.2013.11.017 


\section{Nomenclature}

F Faraday's constant, (Coulombs/mol).

go Gravitational acceleration of the earth, $\left(\mathrm{m} / \mathrm{s}^{2}\right)$.

$H \quad$ Altitude, (metres).

$I_{s t} \quad$ Drawn current from fuel cell stack, (Ampere).

$M_{\mathrm{O}_{2}} \quad$ Molar mass of oxygen, $(\mathrm{g} / \mathrm{mol})$.

$N \quad$ Number of cells in the stack.

$P_{o} \quad$ Pressure of air at sea level, (Pascal).

$R D \quad$ Relative density of air at certain altitude.

$R_{s} \quad$ Specific gas constant of dry air, (J/kg.K)

$T \quad$ Absolute temperature, (Kelvin).

$T_{o} \quad$ Temperature of air at sea level, $\left({ }^{\circ} \mathrm{C}\right)$.

$W_{\text {air }} \quad$ Mass flow rate of contributed air at the reaction interface of the cath-

ode at sea level, $(\mathrm{g} / \mathrm{s})$.

$W_{\text {air,altitude }}$ Mass flow rate of the contributed air at the reaction interface of the cathode at certain altitude, $(\mathrm{g} / \mathrm{s})$.

$W_{\mathrm{O}_{2}} \quad$ Total mass flow rate of the reacted oxygen per second at the cathode interface, $(\mathrm{g} / \mathrm{s})$.

$\rho \quad$ Density of dry air at certain altitude, $\left(\mathrm{kg} / \mathrm{m}^{3}\right)$.

$\rho_{o} \quad$ Density of dry air at sea level, $\left(\mathrm{kg} / \mathrm{m}^{3}\right)$.

\section{Author Biographies}

\section{Ibrahim M. Saleh}

Dr Saleh is currently a Postdoctoral Research Fellow in Electrical Engineering at the University of Lincoln. He optioned his MSc with Distinction in the field of Electrical Engineering and Power Electronics from the University of Bradford in 2007, then his PhD from Sheffield Hallam University in 2016 in the field of PEM fuel cells. Saleh's experience extends over more than twelve years in different professional fields of engineering, such as operation and maintenance, testing and commissioning, sites supervision and inspection, projects management, and consultancy.

\section{Dr Rashid Ali}

Dr Ali joined Coventry University in 2016, as a Senior Lecturer in the School of Mechanical, Aerospace and Automotive Engineering. Before joining Coventry, Ali worked for 3 years as a Senior Lecturer in Flight Simulation and Control in the Department of Engineering and Mathematics at Sheffield Hallam University. He worked as well as a Senior Lecturer at University of Hertfordshire (2004-2014) and a Director of RALI Consultants Limited (1988-2004). He obtained his $\mathrm{PhD}$ in Flight Control Systems in 1985 following his BSc in Mathematics and BTech(Hons) in Aeronautical Engineering from Loughborough University.

\section{Dr Hongwei Zhang}

Dr Zhang joined Sheffield Hallam University in 2007. Currently he is a Principal 
Lecturer in Control Systems and a Group Leader of the Automation and Operations. Before joining Sheffield Hallam, Zhang worked as a Research Associate at The University of Manchester (2001-2003) and then as a Lecturer in Control Engineering at North East Wales Institute, University of Wales (2003-2006). 